\title{
COMMENTS FROM THE EDITOR
}

\section{CHANGE IN ADVISORY EDITORIAL BOARD}

\begin{abstract}
$\Lambda$ fter three and one-half superb years, Nicholas $T$. AKouchoukos has asked to be relieved of his duties as Associate Editor in view of his increasing duties as Vice President and President-Elect of The Society of Thoracic Surgeons. It is with great regret that I accept his resignation; he has been an invaluable member of the editorial team for both his fairness and wisdom in the editorial process. The

Copyright $(1) 1998$ by Mosby, Inc. $0022-5223 / 98 \$ 5.00+0 \quad \mathbf{1 2 / 1 / 9 2 9 0 7}$
\end{abstract}

Society of Thoracic Surgeons surely is fortunate to have a person with these attributes, and we at the Journal wish Dr. Kouchoukos well in his new venture.

I have asked D. Craig Miller to become the Associate Editor for Acquired Cardiovascular Surgery and he has accepted. Dr. Miller will bring to the Journal an in-depth knowledge of this important area of cardiovascular surgery and will continue in the editorial role of his predecessor. We are delighted to have him join us.

John A. Waldhausen, $M D$ 